\title{
ANTIDIABETIC AND ANTIHYPERLIPIDAEMIC EFFECTS OF THE ETHANOL EXTRACT OF THE LEAVES AND STEM OF CISSUS GRACILLIS (GULL ET PERR) (VITACEAE)
}

\author{
OLUSAYO A SHORINWA*, GORDON EI EMENU \\ Department of Experimental Pharmacology and Toxicology, Faculty of Pharmaceutical Sciences, University of Port Harcourt, Port \\ Harcourt, Rivers State, Nigeria. Email: olusayo.shorinwa@uniport.edu.ng
}

Received: 28 August 2021, Revised and Accepted: 20 October 2021

\section{ABSTRACT}

Objectives: This study investigated the antidiabetic and antihyperlipidemic potential of the ethanol extract of the leaves and stem of Cissus gracillis on alloxan monohydrate-induced diabetic albino rats.

Methods: Preliminary phytochemical screening and acute toxicity were carried out. Animals were assigned into seven groups of five rats each. Groups A and B were administered $10 \mathrm{mg} / \mathrm{kg}$ each of glibenclamide and atorvastatin respectively, C, D, and E were given 125,250 and $500 \mathrm{mg} / \mathrm{kg}$ of ethanol extract of $C$. gracillis, respectively, daily for 21 days through oral gavage, group F was diabetic but untreated (diabetic control group), while group $\mathrm{G}$ was non-diabetic and untreated which served as the control group.

Results: Phytochemical screening revealed the presence of steroids/triterpenoids and carbohydrates. $\mathrm{LD}_{50}$ was above $5000 \mathrm{mg} / \mathrm{kg}$. The extract at $500 \mathrm{mg} / \mathrm{kg}$ showed a statistically significant $(\mathrm{p}<0.05)$ decrease in blood glucose level when compared with the glibenclamide group on day 21. However, gradual non- significant reduction in blood glucose levels were observed in the extract treated groups on the $7^{\text {th }}, 14^{\text {th }}$, and $21^{\text {st }}$ days of treatment. The administration of ethanol extract of $C$. gracillis to alloxan-induced diabetic rats produced a decrease in total cholesterol, triglycerides, and low-density lipoproteins comparable to glibenclamide and atorvastatin.

Conclusion: The ethanol extract of the leaves and stem of C. gracillis possess a mildly significant antidiabetic and antihyperlipidemic activity.

Keywords: Antidiabetic, Anti-hyperlipidaemic, Ethanol, Cissus gracillis, Alloxan, Glibenclamide, Atorvastatin.

(C) 2021 The Authors. Published by Innovare Academic Sciences Pvt Ltd. This is an open access article under the CC BY license (http://creativecommons.org/ licenses/by/4.0/) DOI: http://dx.doi.org/10.22159/ajpcr.2021v14i12.43005. Journal homepage: https://innovareacademics.in/journals/index.php/ajpcr

\section{INTRODUCTION}

Diabetes mellitus is defined as a metabolic disorder characterized by a persistent elevation of blood glucose levels associated with absence or inadequate insulin secretion, with or without concurrent impairment of insulin action. Diabetes is usually classified according to the etiology, by far the most common two being type 1 and type 2 diabetes mellitus [1]. Diabetes is a global health problem and accounted for 1.5 million deaths in 2019 [2]. Several pathogenic processes are involved in the development of diabetes, ranging from autoimmune destruction of the $\beta$-cells of the pancreas with consequent insulin deficiency to abnormalities that result in resistance to insulin action. The basis of the abnormalities in carbohydrate, fat, and protein metabolism in diabetes is deficient action of insulin on target tissues. Impairment of insulin secretion and defects in insulin action frequently coexist in the same patient, and it is often unclear which abnormality, if either alone, is the primary cause of the hyperglycemia [3].

Besides hyperglycemia, other symptoms such as hyperlipidemia are involved in the development of microvascular complications of diabetes, which are the major causes of morbidity and death [4]. The World Health Organization has also substantiated the utilization of herbal remedies for the management of diabetes [5].

Management of diabetes without hyperlipidemia and various other associated side effects is still a challenge to the medicinal community. Combination of allopathic and herbal drugs may help to reduce the resistance to insulin and/or oral hypoglycemic therapy and the associated side effects. Hence, the continued research on medicinal plants which may serve as templates or leads for newer drugs.

Abnormalities in lipid profile are one of the most common complications in diabetes mellitus, which is found in about $40 \%$ of diabetes. The level of serum lipids (cholesterol, triglycerides, lowdensity lipoprotein) is usually elevated in diabetes mellitus and such an elevation represents the risk factor for the development of coronary heart disease [6]. Cissus gracillis is an herbaceous, perennial climbing plant producing slender stem up to $7.5 \mathrm{~m}$ long. The stem crumbles over the ground, climbing into the surrounding vegetation and attaching themselves by the use of tendrils. The plant is sometimes harvested from the wild, mainly as a medicinal, but sometimes also as food [7]. It is known as Anaya or Yaakuwarfataakke (Hausa), Okwukwo-iri nwere-omughor (Ikwerre) in Nigeria [8]. However, some plants in the genus Cissus such as Cissus sycoidesis and Cissus quadrangularis have been reported to have antidiabetic and anti-hyperlipidaemic activity $[9,10]$. This present study examined the antidiabetic potential and the antihyperlipidaemic effects of ethanol extract of $C$. gracillis.

\section{METHODS}

\section{Collection of plant materials}

The plant C. gracillis was collected in Obelle Town, Emohua Local Government Area of Rivers State, Nigeria. Authentication was done by Dr. Ekeke Chimezie of the Department of Plant Science and Biotechnology, University of Port Harcourt with the herbarium number $\mathrm{UPH} / \mathrm{V} / 1249$.

\section{Plant extract preparation}

The plant $C$. gracillis was collected, cleaned, shade dried for 2 weeks, and pulverized using a mechanical grinder. The plant powder $(3.7 \mathrm{~kg})$ was subjected to solvent extraction for $72 \mathrm{~h}$ with $17.84 \mathrm{~L}$ of absolute ethanol. The extract was concentrated using rotary evaporator and carefully evaporated to dryness over a water bath at $45^{\circ} \mathrm{C}$ while the dried extract was stored in a refrigerator. 


\section{Animals used}

A total of 47 healthy albino rats of average weight of $200 \mathrm{~g}$ was used. The animals were procured from the Department of Pharmacology, acclimatized, and fed with standard feeds (Top feed broiler finisher manufactured by Premier Feed Mills Company limited, Cross Rivers State, Nigeria) and water ad-libitum under hygienic condition.

\section{Phytochemical screening test}

Preliminary screening of the ethanol crude extract of C. gracillis was carried out to determine the presence of its constituents [11]. The intensity of the coloration and precipitates formed determined the abundance of the compound present.

\section{Acute toxicological evaluation}

The acute toxicity study of the plant extract was determined using modified [12] Lorke's method with 18 healthy albino rats. The study was in two phases with 9 healthy albino rats each. In the first phase, the animals were randomly distributed to three groups of three animals each and treated with the ethanol extract of C. gracillis at doses of 10 , 100 , and $1000 \mathrm{mg} / \mathrm{kg}$ orally. The animals were kept under observation for $24 \mathrm{~h}$ for signs of acute toxicity and death.

In the second phase, three groups of three healthy albino rats each were administered with the ethanol extract of $C$. gracillis at doses of 1600 , 2900 , and $5000 \mathrm{mg} / \mathrm{kg}$ and were keenly observed for $24 \mathrm{~h}$ for signs of mortality and death.

\section{Induction of diabetes mellitus}

Diabetes was induced by intraperitoneal injection of alloxan monohydrate at a dose of $165 \mathrm{mg} / \mathrm{kg}$ body weight dissolved in cold normal saline. After a period of $72 \mathrm{~h}$, the rats with fasting blood glucose levels $>200 \mathrm{mg} / \mathrm{dl}$ were considered diabetic and thus selected for the study [13].

\section{Evaluation of anti-diabetic and anti-hyperlipidaemic activity}

The rats were allotted into seven groups of five rats each. Treatment was done daily for 21 days consecutively through oral gavage as outlined below:

1. Group A: Diabetic rats with glibenclamide $(10 \mathrm{mg} / \mathrm{kg})$

2. Group B: Diabetic rats with atorvastatin $(10 \mathrm{mg} / \mathrm{kg})$

3. Group C: Diabetic rats with C. gracillis extract $(250 \mathrm{mg} / \mathrm{kg})$

4. Group D: Diabetic rats with C. gracillis extract $(500 \mathrm{mg} / \mathrm{kg})$

5. Group E: Diabetic rats with C. gracillis extract $(1000 \mathrm{mg} / \mathrm{kg})$

6. Group F: Diabetic untreated

7. Group G: Non-diabetic control.

Normal control and diabetic untreated animal groups received distilled water and standard feed. Body weights and the fasting blood glucose levels of all the animals were recorded at regular interval during the experimental period. Blood samples were collected from the tail tip of the animals on days $0,7,14$, and 21 , respectively. This was done with the aid of Accu-check glucometer test strips.

All the rats were sacrificed under anesthesia with diethyl ether at the end of the study and blood samples were analyzed for lipid profile parameters vis total cholesterol, triglycerides, high-density lipoprotein, and low-density lipoprotein at the Department of Chemical Pathology, the University of Port Harcourt with Randox kit (Randox lab. UK) and following the standard procedures as described by the manufacturers. The Low-density lipoprotein-cholesterol was calculated using Friedwald's equation [14,15]. Ethics approval was obtained from the University of Port Harcourt research ethics committee with the reference number UPH/RandD/REC/04.

\section{Statistical analysis}

All the results obtained were analyzed using one-way analysis of variance followed by Student's t-test with SPSS version 23. Comparison was done between treatment groups and control groups. p-values at $\mathrm{p}<0.05$ were taken as significant.

\section{RESULTS}

\section{Qualitative phytochemical screening}

Qualitative phytochemical screening of the ethanol extract of the leaves and stem of $C$. gracillis revealed alkaloids, carbohydrates, cardenolides, and triterpenoids/steroids as its phytoconstituents while flavonoids, tannins, saponins, and anthraquinones were absent.

\section{Acute toxicity}

The result of the oral acute toxicity studies showed that the $\mathrm{LD}_{50}$ of the ethanol extract of C. gracillis was above $5000 \mathrm{mg} / \mathrm{kg}$ body weight. However, the main signs of acute toxicity observed was itching in the mouth which was highest with the dose of $5000 \mathrm{mg} / \mathrm{kg}$.

\section{Effect of the extract on blood glucose concentration}

The extract at $500 \mathrm{mg} / \mathrm{kg}$ showed a statistically significant $(\mathrm{p}<0.05)$ decrease in blood glucose level when compared with the glibenclamide group on day 21 (Fig. 1).

\section{Effect of the extract on lipid profile of albino rats}

The extract at $125 \mathrm{mg} / \mathrm{kg}$ had a comparable total cholesterol value with the positive control group. The extract at $500 \mathrm{mg} / \mathrm{kg}$ exhibited a non-significant reduction in triglycerides level in comparison with the positive control and diabetic control groups. Treatment with the ethanol extract of $C$. gracillis showed a non-significant decrease in lowdensity lipoproteins at $125 \mathrm{mg} / \mathrm{kg}$ when compared with the diabetic untreated group (Fig. 2).

\section{DISCUSSION}

Diabetes mellitus which is a chronic metabolic syndrome is associated with abnormally high blood glucose level as a result of insufficient secretion or resistance to insulin. This study evaluated the potential antidiabetic and anti-hyperlipidemic activities of ethanol extract of the leaves and stem of $C$. gracillis. At least a dozen plants from the genus Cissus have been used for treating various ailments in traditional medicines in different parts of the world. The qualitative phytochemical screening of the extract showed the presence of alkaloids, carbohydrates, triterpenoids, and cardenolides. This result can be related to studies done by Deokule and Waghmare [16], which showed that the phytochemical screening of $C$. quadrangularis and C. sycoidesis contained sterols/ triterpenoids, stilbens, iridoids, and had anti-diabetic and antilipidemic activities [17-19]. The oral acute toxicity of the ethanol extract of leaves and stems of $C$. gracillis showed only a mild itching in the mouth which was highest at the dose of $5000 \mathrm{mg} / \mathrm{kg}$ without any other adverse effect or mortality even at $5000 \mathrm{mg} / \mathrm{kg}$, it could be said that the plant is very safe [12]. This result can be correlated to the report of Enechi [20], that the oral $\mathrm{LD}_{50}$ of the ethanol extract of the root of $C$. quadrangularis was greater than $5000 \mathrm{mg} / \mathrm{kg}$.

Alloxan monohydrate causes enormous reduction in insulin release through the destruction of beta cells of the Islet of Langerhans, thereby inducing hyperglycemia [21]. In vitro studies have shown that alloxan monohydrate is selectively toxic to pancreatic beta cells causing cell necrosis. The cytotoxic action of alloxan monohydrate is mediated by the production of reactive oxygen species with resultant fragmentation of DNA of pancreatic cells [22]. In this study, the extract at $500 \mathrm{mg} / \mathrm{kg}$ showed a statistically significant $(p<0.05)$ decrease in blood glucose level when compared with the glibenclamide group on day 21. However, gradual reduction in blood glucose levels was observed in the extracttreated groups on the $7^{\text {th }}, 14^{\text {th }}$ and $21^{\text {st }}$ days of treatment but could not considered to be significant. This result indicates a mild antidiabetic activity of the leaves and stem of $C$. gracillis. The mechanism by which C. gracillis may be eliciting its antidiabetic effect may be through the potentiation of pancreatic secretion of insulin from beta cells of islets of Langerhan or due to enhanced transportation and utilization of insulin in the peripheral tissues which can be corroborated with the reports of [23] on aqueous leaf extract of Millettia aboensis. The administration of ethanol extract of $C$. gracillis to alloxan-induced diabetic rats produced a decrease in total cholesterol, triglycerides, 


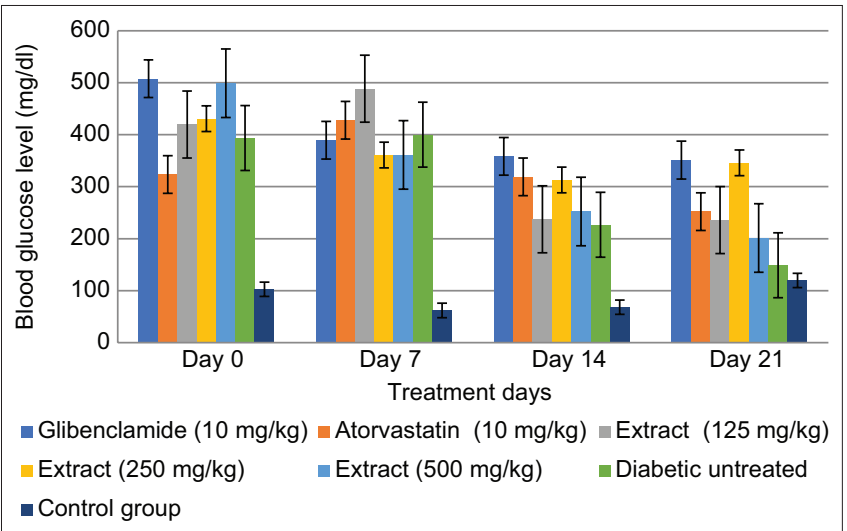

Fig. 1: Effect of Cissus gracillis on blood glucose concentrations of alloxan-induced diabetic rats

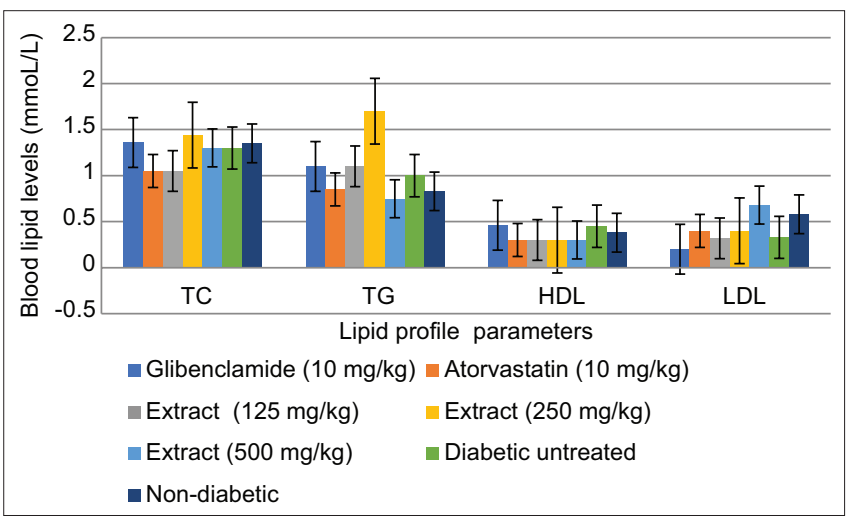

Fig. 2: Effect of Cissus gracillis on lipid profile of alloxan-induced diabetic rats, Values are represented as mean \pm SEM. TC: Total cholesterol, TG: Triglycerides, HDL: High density lipoprotein while LDL: Low density lipoprotein

and low-density lipoproteins which were comparable to glibenclamide and atorvastatin effects. This showed the protective effect of $C$. gracillis against the development of hyperlipidaemia. This can be related to the findings of [24] which stated that Mimosa pudica extract possessed anti-hyperlipidaemic effect. The antidiabetic and antihyperlipidaemic of $C$. gracillis may be attributed to the presence of alkaloids and triterpenoids as its phytoconstituents [25] while the absence of flavonoids and tannins in the extract may also be responsible for its inability to exhibit a pronounced antidiabetic activity [26].

\section{CONCLUSION}

The findings of this study have revealed that the ethanol extract of $C$. gracillis possess mild anti-diabetic activity and anti-hyperlipidaemic activity which may be due to the presence of alkaloids and triterpenoids as its biologically active constituents.

\section{AUTHORS CONTRIBUTIONS}

Author OAS conceptualized, designed, and supervised the study with the experimental work, while author GEIE carried out the study. Both authors drafted the manuscript while author AOS wrote the final manuscript.

\section{CONFLICT OF INTEREST}

The authors hereby declare that no conflict of interest exists.

\section{FUNDING}

No external funding was received for this study.

\section{REFERENCES}

1. Belhekar SN, Chaudhari PD, Saryawanshi IJ, Mali KK, Pandhare RB. Antidiabetic and anti-hyperlipidemic effects of Thespesia populnea fruit pulp extracts on alloxan-induced diabetic rats. Indian J Pharm Sci 2013;75:217-21

2. World Health Organization. Global Reports on Diabetes. Available from: http://www.who.int

3. Diabetes Care; 2010. Available form: https://doi.org/10.2337/ dc10-S062. [Last accessed on 2010 Jan 29].

4. Taskinen MR. Diabetic dyslipidaemia. National center for biotechnology information. Atherosclerosis Suppl 2002;3:47-51.

5. Bailey CJ, Turner RC. Metformin. N Engl J Med 1996;34:574-9.

6. Rajagopal K, Sasikala K. Anti-hyperglycaemic and anti-hyperlipidaemia effects of Nympha eastellata in alloxan-monohydrate-induced diabetic rats. Singa Med J 2008;49:137-41.

7. Tropical Plants Database, Ken Fern. tropical.theferns.info. 2021-11-24; 1973.

8. Burkill HM. The useful plants of west Tropical African. $2^{\text {nd }}$ ed., Vol. 5. Richmond, United Kingdom: Royal Botanic Gardens, Kew; 2000. p. 686.

9. Oben J, Kuate D, Agbor G, Momo C, Talla X The use of a Cissus quadrangularis formulation in the management of weight loss and metabolic syndrome. Lipids Health Dis 2006;5:1-7.

10. Salgado JM, Mansi NR, Gagliardi A. Cissus sicyoides: Analysis of glycemic control in diabetic rats through biomarkers. J Med Food 2009;12:722-7.

11. Harborne JB. Phytochemical Methods: A Guide to Modern Techniques of Plant Analysis. $3^{\text {rd }}$ ed. London, UK: Chapman and Hall; 1998.

12. Lorke D. A new approach to acute toxicity testing. Arch Tox 1983;54:275-89.

13. Jude E, Bassey A, John A. Antidiabetic activities of ethanolic extract and fraction of Anthocleista djalonnensis. Asian Pac J Trop Biomed 2012;2:461-4.

14. Friedewald WT, Levy RI, Fredrickson DS. Estimation of the concentration of low-density lipoprotein cholesterol in plasma, without use of the preparative ultracentrifuge. Clin Chem 1972;18:499-502.

15. Trinde P. Enzymatic calorimetric determination of triglycerides by GOP-PAP method. Ann Clin Biochem 1969;6:24-7.

16. Descoing B. Classification of Grassy Formation by the Structure of the Vegetation. United States: Tropical Plants Database, Ken Fern Tropical Theferns Info; 2021.

17. Beltrame FL, Pessini GL, Doro DL, Dias Filho BD, Bazotte RB, Corte DA. Evaluation of the antidiabetic and antibacterial activity of Cissus sicyoides. Braz Arch Boil Tech 2002;45:21-5.

18. Otshudi AL, Foriers A, Vercruysse A, Van Zeebroeck A, Lauwers S. In vitro antimicrobial activity of six medicinal plants traditionally used for the treatment of dysentery and diarrhoea in democratic republic of Congo (DRC). Phytomedicine 2000;7:167-72.

19. Xu F, Matsuda H, Hata H, Sugawara K, Nakamura S, Yoshikawa M. Structures of new flavonoids and benzofuran-type stilbene and degranulation inhibitors of rat basophilic leukemia cells from the Brazilian herbal medicine Cissus sicyoides. Chem Pharm Bull 2009:57:1089-95.

20. Enechi, OC, Igbonekwu CN, Ugwu Okechukwu PC. Effects of ethanol extract of Cissus quadrangularis on induced gastric ulcer in rats. Afr J Biotech 2013;12:6197-202.

21. Goldner M, Gomori G. Alloxan induced diabetes. Endocrinology 1943;33:297-9.

22. Shankar MB, Parikh JR, Geetha M, Mehta RS, Saluja AK. Anti-diabetic activity of novel androstane derivatives from Syzygium cuminii Linn. J Nat Remed 2007;7:214-9.

23. Onyegeme-Okerenta BM, Essien EB. Evaluation of antidiabetic and anti-lipidaemic activities of aqueous leaf extract of Millettia aboensis and its effect on pancreatic histology of alloxan-induced diabetic rats. Adv Biochem 2015;3:24-9.

24. Subramani P, Teoh Huey C, Chong Hao L, Urmila B. Antidiabetic and antihyperlipidemic effects of a methanolic extract of Mimosa pudica (Fabaceae) in diabetic rats. Egypt J B Appl Sci 2019;6:137-48.

25. Lopez PM, Mora PG, Wysocka W, Maiztegui B, Alzugaray ME, Zoto HD, et al. Quinolizidine alkaloids isolated from Lupinus species enhance insulin secretion. Eur J Pharm 2004;504:139-42.

26. Den Hartogh DJ, Tsiani E. Antidiabetic properties of naringenin: A citrus fruit polyphenol. Biomolecules 2019;9:99. 